\title{
The Mediating Role of Brand Love in the Relationship Between Consumer- Based Brand Equity and Brand Loyalty: a Research on Starbucks
}

\author{
Aylin Sinem Polat \\ Tourism Faculty Department of Gastronomy and Culinary Arts, Mersin University, Mersin, Turkey \\ Burçin Cevdet Çetinsöz \\ Tourism Faculty Department of Tourism Management, Alanya Alaaddin Keykubat University, Alanya, Turkey
}

Received: 18 March 2021. Revision received: 12 April 2021. Accepted: 9 May 2021

\begin{abstract}
The present study aims to determine the mediating role of brand love in the relationship between CBBE and brand loyalty. The study makes an analysis of CBBE, brand loyalty, and brand love related to Starbucks - a global coffee house and roastery catering concept. The study population comprises customers of the Starbucks enterprises operating in the city of Mersin, Turkey, and adopts a convenience sampling method. During the data collection process, 384 customers of Starbucks stores within Mersin who were over 18 years of age were surveyed. The dependent variables of the study are "brand loyalty" and "brand love," whereas the independent variable is "CBBE". The hypotheses developed in the research model were tested through structural equation modeling (SEM). Based on the study findings, it was concluded that brand love, as well as the dimensions of CBBE of "Service Quality: Physical Quality SQ:PQ" and "Lifestyle-Congruence LC", had full mediation with brand loyalty, while "Service Quality: Staff Behavior SQ:SB", "Ideal Self-Congruence IS-C" and "Brand Identification BI" had no such mediating effect on brand loyalty. In the study, the mediating role of brand love in terms of the impact of CBBE in the service industry on brand loyalty has been examined for the first time. The research findings show that a strong bond will be established with the target audience through compatible and parallel strategies that will be implemented by the managers on the SQ:PQ and LC dimensions of CBBE and this situation will increase loyalty to the brand. As a result of the consumers' strong emotions and their increasing loyalty towards the brand, this situation will lead the businesses in the service industry to protect their market share along with having a positive impact on their sustainable competition and profitability.
\end{abstract}

Key Words: brand love, cbbe, brand loyalty, service industry, mediating role, starbucks

JEL Classification: M31, L83

Reference: Polat, A.S. \& Çetinsöz, B.C. (2021). The Mediating Role of Brand Love in the Relationship Between Consumer-Based Brand Equity and Brand Loyalty: a Research on Starbucks. Journal of Tourism and Services, 22(12), 150-167. doi: 10.29036/jots.v12i22.252

\section{Introduction}

Brand loyalty is among the most common research topics in marketing, and is considered essential for the success of enterprises in the long term (Han, Kwortnik \& Wang, 2008; Nam, Ekinci \& Whyatt, 2011; Shin, Hwang, Lee \& Cho, 2015), as it is brand loyalty that brings in loyal customers who buy products on a frequent basis, and who try other products and services (facilitating cross selling) plays a crucial role for firms in terms of gaining new customers and developing a positive social image (Tu, Wang \& Chang, 2012). Businesses are able to gain more market share through brand loyalty, which leads loyal 


\section{JOURNAL OF TOURISM AND SERVICES}

Issue 22, volume 12, ISSN 1804-5650 (Online)

www.jots.cz

customers to purchase the products of their preferred brand, despite the marketing activities of its competitors and situational factors (Yoo, 2009).

Brand equity, as a theoretical concept has been research in the 80's (Grębosz-Krawczyk, 2018). Aaker (1991) has defined brand equity as "all assets and liabilities linked to the distinctive features of the brand such as name and symbol which increase or decrease the value of the products and the services a business provides to the consumers". Various approaches have been established to evaluate brand equity. The first approach is the behavioral approach consisting of consumer's attitudes and behaviors in evaluating brand equity. The second approach is the financial approach consisting of the calculation of the financial statements in determining the total brand equity (Grębosz-Krawczyk, 2018).

Abdullah et al. (2018) have indicated that brand equity plays an essential role in structuring consumer behavior, attitude and preferences. Therefore, the concept of CBBE has gained importance for the researchers in recent years. Jorfi \& Gayem (2016) claims that CBBE and its different dimensions are important for enterprises on account of its effect on consumer satisfaction, perceived value and consumer loyalty. Aaker (1991) states that CBBE can be provided by means of quality perception, brand association, brand loyalty and brand awareness. Keller (1993), on the other hand, claims that CBBE "is the impact that brand knowledge has on different buyer responses to the marketing of a brand". In another study, CBBE has been defined as "the total symbolic and functional benefits obtained by the consumer as a result of utilizing and consuming the brand" (Vazquez et al., 2002:28). Yoo et al. (2000) on the other hand, have defined CBBE as, "a value added by the brand name or the increasing benefits". CBBE is based on both consumer perception and consumer behavior, referred to as cognitive and attitudinal effects (Şimşek, 2019).

$\mathrm{CBBE}$ is treated as multidimensional in marketing literature, although the same body of literature features discussions of whether the principles behind the creation of brand awareness can be applied directly to brands such as hotels and food and beverage establishments, in which the service element is dominant. For instance, Aaker (1991) defines perceived quality as one of the elements of brand equity, but doesn't indicate clearly whether it refers to goods or services. Furthermore, Aaker (1991) and other studies offer no explanation which quality elements should be counted in the brand equity model, and whether it is feasible to evaluate brand equity models, such as hotels and restaurants, in which the service aspect is dominant. Adaptations to the service-based branding models are necessary to satisfy the peculiar features of service provision (i.e. non-physical), as the different dimensions of brand equity are revealed when brands are evaluated in the service industry (Souri, 2017; Nam, Ekinci \& Whyatt, 2011). In their measurement of CBBE in the service sector, Nam et al. (2011) suggested that accomplished brands are not planned not only to gratify physical consumer needs but also to meet their symbolic needs.

Brand love, which has attracted little academic interest to date, has started to emerge as a novel marketing phenomenon that is attracting the attention of academicians as much as sectoral practitioners (Bergkvist \& Larsen, 2010). According to Roberts (2004), CEO of Saatchi \& Saatchi, a long-dated correlation between the brand and the customer, and the level of brand loyalty in the customer base is linked to the love attached to the brand, and states that brands such as Harley Davidson, Apple and Starbucks have all achieved success through brand love. Brand love is an emotion that has a positive impact on buyer, and ensures that customers remain "loyal customers", regardless of the prices; to talk positively about the brand; and even to feel an emotional attachment to it (Carroll \& Ahuvia, 2006; Kalyoncuoğlu, 2017).

Rapid technological advancements have led to the popularity of the concept of modern coffee houses and roasteries to increase gradually in the 21 st century. Brand equity must be increased if sustainability is to be maintained in the catering sector, which is based on a modern coffee house and roastery concept in the case of Starbucks (Ongkowidjoyo, 2015). Starbucks ranks 24th in the world in the "BrandZ Top 100" global brands list in 2020 with a brand value of 47.7 billion dollars (ntv.com.tr, 2020). Today, Starbucks offers coffee drinks to millions of customers every day, with more than 24,000 retail stores in 73 countries (Starbucks, 2021). 


\section{JOURNAL OF TOURISM AND SERVICES}

Issue 22, volume 12, ISSN 1804-5650 (Online)

www.jots.cz

The present study seeks to determine the intermediary role of brand love in the correlation between $\mathrm{CBBE}$ and brand loyalty, addressing the issues of brand equity, brand loyalty and the brand love phenomenon through an analysis of Starbucks and the sale of coffee on a global scale. In previous studies, while in general, the effect of brand equity on brand loyalty and the intermediary role of buyer satisfaction have been assessed (Souri,2017; Jorfi \& Gayem, 2016; Ali \& Muqadas, 2015; Shahroodi, Kaviani \& Abasian, 2015; Ongkowidjoyo, 2015; Susanty \& Kenny, 2015; Nam, Ekinci \& Whyatt, 2011), there have also been those studying the effect of brand trust on brand loyalty and the intermediary role of brand love (Kalyoncuoğlu, 2017); brand trust, brand awareness and the intermediary role of brand love on the effect of self-image congruence on brand commitment (Aydın, 2017); and the intermediary effect of brand love in the correlation between brand experience and brand loyalty (Aşkın \& İpek, 2016).

In the first part of the study, consumer-based brand equity (CBBE) and its dimensions were explained conceptionally. Furthermore, in this part, previously analyzed consumer-based brand equity $(\mathrm{CBBE})$ and the relevant literature researching the relationship between brand love and brand loyalty were examined. Research model was established in accordance with the obtained data. In the third part, research method and data validity and reliability analysis were conducted. In the fourth part of the study, research hypothesis analysis were examined. Finally, research results were compared with previous studies in accordance with the obtained data. Moreover, the reflections of the research results in terms of sectoral perspective and in the literature were specified.

Mediation test is a highly effective method to prove "how" the relationships between variables arise (Şimşek, 2007: 143). Therefore, in the service industry, it is projected that the impact of CBBE will be provided by various mediating variables as well as brand love. In this context, the determination of the mediating effect of brand love is considered to be a very important issue. In the current research, the role of brand love on $\mathrm{CBBE}$ and loyalty will be researched for the first time. It is projected that the research results will contribute to profitability in the sector through the creation of a sustainable competitive advantage, while also serving as a guide to enterprises seeking to increase the customer loyalty by emphasizing certain concepts, and contributing to the related body of marketing literature.

\section{Literature review}

\subsection{Consumer-Based Brand Equity}

Maintaining positive CBBE is necessary for marketing experts (Jorfi \& Gayem, 2016). Each component (physical quality, staff behavior, ideal internal consistency, brand identity, life style consistency) of brand equity is an indication of one's customers' perceptions and imagination in respect to the brand, and this image they create supports the consumer in their purchasing decisions (Shahroodi et al., 2015). Although CBBE is considered to be multidimensional (brand awareness, brand image) in marketing literature (Keller, 1993), discussion continues as to whether branding principles in the marketing of products manufactured in the industrial sector, the agricultural sector and other sectors, can be carried out to brands providing service-weighted products, such as hotels and catering businesses (Nam et al., 2011). In his study, Aaker (1991) did not specify which quality components should be included in the brand equity model, and whether the brand equity model could be applied successfully in such service-based sectors as tourism. For example, it is argued that good-based brand equity models exhibit a slight validity in service-based brand equity models, such as those applied to the tourism sector (Boo et al., 2009). That said, the CBBE model operates differently in the service sector due to the structural differences of the sector (in features such as abstractness, synchronicity, non-storability, heterogeneity, etc.). This led Nam et al. (2011) to determine CBBE dimensions in the service industry through the utilization of Aaker's (1991) dimensions (Service Quality: Phycsical Quality, Service Quality: Staff Behavior, Ideal Self-Congruence, Brand Identification, Lifestyle-Congruence), and to state that these dimensions effect brand loyalty. Nam et al. (2011) made use of these five dimensions measure CBBE in the hotel and 


\section{JOURNAL OF TOURISM AND SERVICES}

Issue 22, volume 12, ISSN 1804-5650 (Online)

www.jots.cz

restaurant sectors, and these same five dimensions will be used also in the present study for the investigation of Starbucks - a global coffee house and roastery catering concept - and the measurement of CBBE. Nam et al. (2011) and Sürücü et al. (2019) also looked into "physical quality" and "staff behavior" in their studies, as the two most effective functional dimensions in the services sector, and these two quality dimensions are also addressed in the present study, making use of the data obtained by Nam et al. for the measurement of CBBE.

Service Quality: Physical Quality (SQ:PQ) refers to the equipment, design, materials and the general appearance of the facilities of the enterprise in a service business (Madanoğlu, 2004), although brand loyalty among consumers is being measured increasingly based on perceived service quality (HemsleyBrown \& Alnawas, 2016). Moreover, the physical environment is also influential in the recommendations made by customers related to the service they receive to their inner circle in the event of them being satisfied and maintaining their purchasing continuity (Susanty \& Kenny, 2015: 15).

Service Quality: Staff Behavior (SQ:SB) is the image that is projected based on the skills, benevolence, sincerity and sensitivity of the accommodation and food and beverage staff (Ekinci et al., 2008; Madanoglu, 2004). The workforce of an enterprise is important in shaping customer perception and satisfaction, being the component of the business that is responsible for the provision of quality service in accordance with customer expectations (Zeithaml, Berry \& Parasuraman, 1996).

Ideal Self-Congruence (IS-C) self-conception can be considered as the integrity of an individual's ideas and feelings with reference to the person as an object of thought (Rosenberg, 1979). Self-congruence reflects to what extent the consumer's true self or ideal self conception coincides with a brand image (Nam et al., 2011; Sirgy, Grewal, \& Mangleburg, 2000). The more a brand projects the consumers' self, the more powerful a personal connection the consumer will develop with the brand (Aaker et al., 2004; Park et al., 2010). Astakhova et al. (2017) suggests that a meaningful and positive relationship exists between the ideal self-congruence and the obsessive brand passion of a consumer. Köksal and Demir (2012) have determined in their studies that Ideal Self-Congruence (IS-C) has a positive impact on brand loyalty through brand love.

Brand Identification (BI) delivers what a brand provides or represents to consumers (Keller, 2008), and satisfies the symbolic needs of consumers more than their functional needs (He et al., 2012). Alnawas \& Altarifi (2015) and Sallam (2014) established in their study that a meaningful and positive relationship exists between brand identification and brand love, and that brand identification makes important contributions to the improvement of brand love.

Lifestyle-Congruence (LC) indicates the extent to which the brand effects buyer lifestyles (Nam et al., 2011), refers to the ability of the brand to support their buyers' values and lifestyles, and their expressions of the same within their social environments (Keller, 2008). Majerova (2020) identified life-style congruence as one of the optimum components of brand value sources. The greater the level of congruence for a brand's image in respect of a buyer's personal lifestyle, the greater the level of buyer satisfaction related to brand experience and brand love (Nam et al., 2011).

Finally, in addition to all these dimensions, Sürücü et al. (2019) have indicated in their studies that CBBE has a direct influence on brand loyalty. According to the data obtained from the literature, H1 hypothesis and its sub-hypotheses had been established for CBBE and its sub-dimensions.

H1: Brand equity, as perceived by consumers, has a significant positive effect on their brand loyalty.

\subsection{Brand Love}

Customers may consider a brand as an individual, and so may feel a similar level of love for a brand as they do a person (Ranjbarian, Kazemi \& Borandeg, 2013). When a consumer starts to love a brand, they may actually become considerably emotional and passionate. They may purchase this brand continuously, turning a blind eye to other brands, as a result of this emotional bond they create (Carroll 


\section{JOURNAL OF TOURISM AND SERVICES}

Issue 22, volume 12, ISSN 1804-5650 (Online)

www.jots.cz

\& Ahuvia, 2006). Furthermore, consumers who build strong emotions towards the brand are willing to pay more money for this brand; therefore, brand love contributes to the financial value of brand in the long term (Başkol \& Asar, 2019).

Gomez \& Perez (2018) identified a meaningful and positive relationship between brand equity and brand love, while in the studies of Carroll \& Ahuvia (2006), it is argued that the more hedonic a product and/or how well it expresses itself, the more it will be liked and loved in terms of consumer tendencies. Önen (2018) on the other hand, have determined that brand equity has an important influence on brand love in the study conducted by Aaker (1991) on the dimensions of brand equity (brand awareness, brand association, brand loyalty and the perceived quality).

In accordance with the data obtained from the literature, $\mathrm{H} 2$ hypothesis and its sub-hypotheses have been established for CBBE and its sub-dimensions.

H2: Brand equity, as perceived by consumers, has a significant positive effect on their brand love.

\subsection{Brand loyalty}

Consumer loyalty refers to the level of attachment of the consumer to a certain brand (Rather \& Camilleri, 2019). In Aaker's brand equity model, loyalty refers to lowering the marketing costs, gaining new customers (building awareness and trust) and a commercial support on account of responding competitive threats (Gil et al, 2007). Traditionally, loyalty is regarded as a dimension of Aaker (1991) 's brand equity model. Many previous studies support this (Başkol \& Asar, 2019; Önen, 2018; Kim \& Chao, 2018; Ongkowidjoyo, 2015). However, most of the studies on service industry considers loyalty as a result of brand equity (Tanushan \& Kennedy, 2020; Souri, 2017; Susanty, et al.,2015; Nam, et.al., 2011).

Although brand love has arisen as a significant structure in the consumer-brand relationship, there have been few studies to date on the source of the love connection between a consumer and a brand, and the potential behavioral consequences (for example, loyalty). For example, brand love may be affected by the characteristics of the product or the brand (for example, a hedonic product where the primary benefit is entertainment, joy or pleasure) and it can also have an influence on the loyalty to the brand (Batra et al., 2012; Carroll \& Ahuvia, 2006). As such, brand love can be considered an initiator of brand loyalty (Bergkvist et al., 2010; Kamat \& Parulekar, 2007) that not only affects consumers' behavioral intentions and attitudinal preferences, but that also influences their insistent loyalty to the brand. The findings of previous studies demonstrate that a meaningful and positive relationship exists between brand love and brand loyalty (Alnawas \& Altarifi, 2015; Loureiro, et al., 2012; Filho, Monteiro \& Souki, 2010; Carroll \& Ahuvia, 2006).

Several studies have been carried out into the intermediary role of the satisfaction variable in the impact of brand equity and brand loyalty (Tanushan \& Kennedy, 2020; Souri,2017; Jorfi \& Gayem, 2016; Ali \& Muqadas, 2015; Shahroodi, Kaviani \& Abasian, 2015; Ongkowidjoyo, 2015; Susanty \& Kenny, 2015; Nam, Ekinci \& Whyatt, 2011). Kalyoncuoğlu (2017) has defined brand trust as the customers' trust to the existing brand in the event of a risky situation they might encounter and stated that brand love has a full mediating role on the relationship between trust towards the brand and brand loyalty. In other words, they have determined that the impact of the customer's trust towards the Starbucks on brand loyalty actualizes through brand love. In their research result, Asskın and İpek (2016) have stated that brand experience plays a significant role in establishing customer satisfaction and transforming it into brand loyalty afterwards and that brand love has a full mediating role on the relationship between brand experience and brand loyalty. In their next study on alimentary goods, Majerova et al. (2020) determined that sources of brand value (image, benefit, attitude and quality) had no significant effect on the perceptions of loyal and disloyal customers. 


\section{JOURNAL OF TOURISM AND SERVICES}

Issue 22, volume 12, ISSN 1804-5650 (Online)

www.jots.cz

To date, however, there has been no study investigating the mediating role of brand love in CBBE and its effect on brand loyalty. The present study makes use of the data from previous studies to achieve the primary purpose of the study by developing $\mathrm{H} 3$ and its sub-hypothesis.

H3: Brand love plays a mediating role in the impact on brand loyalty of consumer perceptions of brand equity.

Figure 1. Theoretical Model

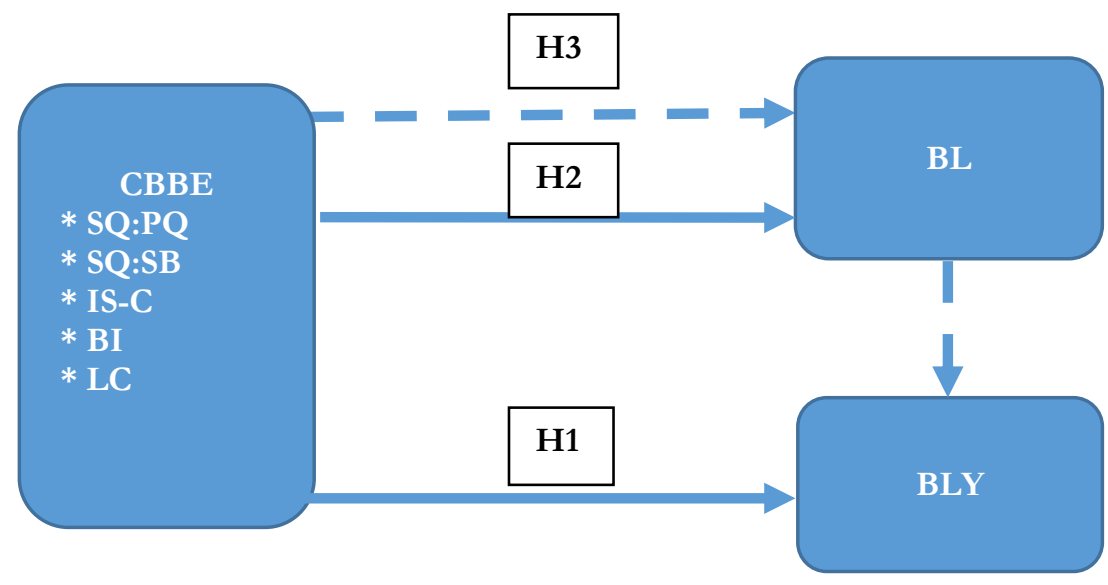

Source: own

\section{Methodology}

The present study aims to determine the mediating role of brand love in the relationship between $\mathrm{CBBE}$ and brand loyalty. The study investigates the factors of brand equity, brand loyalty and brand love through an analysis of Starbucks - a global coffee house and roastery catering concept.

\subsection{Sampling and data collection}

A questionnaire technique was adopted for the study, being a recognized quantitative data collection method. The research questionnaire was applied to patrons of Starbucks in the city of Mersin, Turkey. The study population comprised customers of Starbucks enterprises operating within the city of Mersin, Turkey. A "convenience sampling" approach was adopted for the study, in which individuals who agree to be involved in the sampling are included, rather than all those constituting the study population (Ural \& Kilıç 2006:44). Accordingly, a sample size was calculated using the formula (NEA 1965; Sekaran 2003; Altunış1k et al., 2005) suggested for large populations and quantitative research. There are three Starbucks operations in total within the boundaries of the city center of Mersin, Turkey. The sample size table was used where indicated by Yazıcıoğlu \& Erdoğan (2004: 49-50), recommending a sample size of 384 in the event of the population representing a high target with a sampling error of $\mathrm{d}=+-0.05$ and a confidence interval of $\mathrm{p}=0.05, \mathrm{q}=0.05$, since the number of customers of the Starbucks operations in Mersin who are over 18 years of age cannot be precisely known.

\subsection{Questionnaire design}

The research scale comprises four sections, while the "CBBE" scale in the first section consists of five dimensions. The CBBE scale has six representations in the "Service Quality: Physical Quality" dimension, and draws from the studies conducted by Susanty \& Kenny (2015), Nam, Ekinci \& Whyatt (2011) and Madanoğlu (2006). The "Service Quality: Staff Behavior" dimension consists of four representations, drawing upon the studies conducted by Susanty \& Kenny (2015), Nam, Ekinci \& Whyatt (2011) and Sirgy, Grewal \& Mangleburg (2000). The "Ideal Self-Congruence" comprises three representations, having been constituted from the studies conducted by Susanty \& Kenny (2015), Nam, 


\section{JOURNAL OF TOURISM AND SERVICES}

Issue 22, volume 12, ISSN 1804-5650 (Online)

www.jots.cz

Ekinci \& Whyatt (2011) and Back (2005). The "Brand Identification" dimension consists of four representations and was compiled based on the studies conducted by Alnawas \& Altarifi (2015), and Bhattacharya \& Şen (2003); while the "Lifestyle-Congruence" dimension consists of three representations, having been constituted from the studies conducted by Susanty \& Kenny (2015); Nam, Ekinci \& Whyatt (2011). "Brand Love", covered in the second part of the study, consists of nine representations, and was compiled based on the studies conducted by Rodrigues and Reis (2013); Ünal \& Aydin (2013) and Carroll \& Ahuvia (2006). "Brand Loyalty", covered in the third part of the study, consists of four representations, and was compiled based on the studies conducted by Susanty and Kenny (2015); Nam, Ekinci \& Whyatt (2011) and Zeithaml, Berry \& Parasuraman (1996). In the last part of the study, questions are posed inquiring the participants' personal characteristics (gender, age, marital status and educational background) and their frequency of Starbucks purchases. A total of 33 statements were included in the scale.

\subsection{Analysis Methods}

In the study, a frequency analysis was carried out to ascertain the customers' demographic characteristics. The arithmetic mean and standard deviation values of the dimensions "CBBE", "Brand Love" and "Brand Loyalty" were also calculated. A CFA was carried out to determine the construct validity of the scale, and the Cronbach Alpha (CA) value has was calculated to test the reliability of internal consistency. SEM was used to measure the hypotheses in the model, being a comprehensive statistical approach to the testing of models in which casual and reciprocal relationships exist between the observed and the latent variables (Çelik \& Yılmaz, 2013:5).

\subsection{Validity and reliability}

A CFA (Hair et al., 2010: 709) was applied to investigate of the construct validity of the measurement tool, revealing problems in the measurement model's goodness of fit (GIF). Among these problems, the primary ones were the normalized Chi-square (Chi-square GIF obtained by dividing the Chi-square GIF by the degree of freedom) GIF, corresponding to 6.77; and the RMSEA value corresponding to 0.10 . When examining the modification recommendations provided at the end of the output report of the model, it could be observed that the items of "Service Quality: Physical Quality" numbered SQ:PQ1, and the "Brand Love" items numbered BL2, BL4 and BL9 were perceived as similar by the participants, and that a significant improvement in the reduction of the Chi-square value would be achieved should they be excluded from the scale. The CFA was repeated after excluding these four items, and the normalized Chi-square statistic was found to have reduced to 5.11, while the RMSEA had reduced to 0.09 . In response, when the suggested model modifications were re-examined, it was observed that the item "Service Quality: Staff Behavior" numbered SQ:SB4 and the "Brand Love" item numbered BL1 were considered to be similar, and that a significant improvement could be achieved in the reduction of the Chi-square value should they be excluded from the scale. The exclusion of these two items from the scale led to a model being developed with a Chi-square of $4.43(1343.59 / 303)$ and a RMSEA of 0.08 .

When examining the model modification suggestions, it could be observed no problematic items remained in terms of observed variables describing the latent variables. Thereupon, the t-test values, factor loadings and margins of error that emerged in the correlation between the latent variables and the observed variables were re-examined. As can be seen in Table 1, all of the t-values were found to be statistically significant with a significance level of 0.01 , while standardized load values varied between 0.62 and 0.97 .

The composite reliabilities of the constructs ranged from 0.84 to 0.96 . The adequate internal consistency of multiple items for each construct in the seven-factor model all exceeded 0.60 , being the minimum criterion suggested by Bagozzi \& Yi (1988). A convergent validity in the factor structure was first noted, as each indicator's estimated factor loading on its underlying construct was significant (Peter, 1981) and the AVE (average variance extracted) of all seven constructs exceeded the minimum criterion of 0.5 (Fornell \& Larcker, 1981), ranging from 0.51 to 0.89 . 


\section{JOURNAL OF TOURISM AND SERVICES}

Issue 22, volume 12, ISSN 1804-5650 (Online)

www.jots.cz

Table 1. Descriptive statistics on CFA measurement model

\begin{tabular}{|c|c|c|c|c|c|c|c|c|}
\hline Dimensions \& Items & $\bar{X}$ & S.S. & CA & $\begin{array}{c}\mathrm{t}- \\
\text { Value }\end{array}$ & $\begin{array}{l}\text { Std. } \\
\text { Load }\end{array}$ & $\mathbf{R}^{2}$ & CR & AVE \\
\hline Service Quality: Physical Quality (SQ:PQ) & 3.86 & & 0.83 & & & & 0.84 & 0.51 \\
\hline SQPQ2. & 3.82 & 1.05 & & $16.73^{* *}$ & 0.69 & 0.48 & & \\
\hline SQPQ3. & 3.41 & 1.25 & & $17.35^{* *}$ & 0.71 & 0.51 & & \\
\hline SQPQ4. & 3.84 & 1.01 & & $16.55^{* *}$ & 0.69 & 0.47 & & \\
\hline SQPQ5. & 4.33 & 0.83 & & $17.57 * *$ & 0.72 & 0.52 & & \\
\hline SQPQ6. & 3.89 & 1.03 & & $18.29 * *$ & 0.74 & 0.55 & & \\
\hline Service Quality: Staff Behavior (SQ:SB) & 4.01 & & 0.87 & & & & 0.87 & 0,69 \\
\hline SQSB1. & 3.95 & 0.88 & & $21.76^{* *}$ & 0.83 & 0.69 & & \\
\hline SQSB2. & 4.10 & 0.88 & & $23.77 * *$ & 0.88 & 0.77 & & \\
\hline SQSB3. & 3.99 & 0.96 & & $21.34 * *$ & 0.82 & 0.67 & & \\
\hline Ideal Self-congruence (IS-C) & 3.69 & & 0.90 & & & & 0.91 & 0,77 \\
\hline IS-C1. & 3.86 & 0.95 & & $20.99 * *$ & 0.80 & 0.64 & & \\
\hline IS-C2. & 3.69 & 1.06 & & $27.10^{* *}$ & 0.94 & 0.88 & & \\
\hline IS-C3. & 3.52 & 1.10 & & $24.45^{* *}$ & 0.88 & 0.78 & & \\
\hline Brand Identification (BI) & 4.11 & & 0.88 & & & & 0,89 & 0,67 \\
\hline BI1. & 4.01 & 0.96 & & $23.14 * *$ & 0.86 & 0.73 & & \\
\hline $\mathrm{BI} 2$. & 4.14 & 0.89 & & $23.15^{* *}$ & 0.86 & 0.73 & & \\
\hline $\mathrm{BI} 3$. & 4.00 & 0.96 & & $23.17 * *$ & 0.86 & 0.74 & & \\
\hline BI4. & 4.28 & 0.80 & & $16.58 * *$ & 0.68 & 0.46 & & \\
\hline Lifestyle-Congruence (LC) & 3.64 & & 0.95 & & & & 0,96 & 0.89 \\
\hline LC1. & 3.70 & 1.08 & & $27.23 * *$ & 0.93 & 0.87 & & \\
\hline LC2. & 3.65 & 1.08 & & $29.08^{* *}$ & 0.97 & 0.93 & & \\
\hline LC3. & 3.57 & 1.13 & & $27.04 * *$ & 0.93 & 0.86 & & \\
\hline Brand Love (BL) & 3.35 & & 0.96 & & & & 0,96 & 0.83 \\
\hline BL3. & 3.70 & 1.11 & & $21.83 * *$ & 0.81 & 0.66 & & \\
\hline BL5. & 3.21 & 1.28 & & $27.51 * *$ & 0.94 & 0.88 & & \\
\hline BL6. & 3.31 & 1.29 & & $28.02 * *$ & 0.95 & 0.89 & & \\
\hline BL7. & 3.14 & 1.26 & & $27.60 * *$ & 0.94 & 0.88 & & \\
\hline BL8. & 3.39 & 1.21 & & $26.94 * *$ & 0.93 & 0.86 & & \\
\hline Brand Loyalty (BLY) & 3.41 & & 0.83 & & & & 0.85 & 0.58 \\
\hline BLY1. & 3.52 & 1.10 & & $21.76 * *$ & 0.83 & 0.69 & & \\
\hline BLY2. & 4.05 & 0.83 & & $19.80^{* *}$ & 0.79 & 0.61 & & \\
\hline BLY3. & 2.88 & 1.09 & & $14.54 * *$ & 0.62 & 0.38 & & \\
\hline BLY4. & 3.17 & 1.15 & & $20.79 * *$ & 0.81 & 0.65 & & \\
\hline
\end{tabular}

Source: own research

Table 2 presents the reference values for GIF, which indicate that a measurement model has a construct validity, and the statistics for congruity on the measurement model of the study. When the measurement tool's statistics for congruity are compared with the reference values, it can be argued that the measurement model, as a whole, has a GIF, being at an acceptable level and with convergent validity. 


\section{JOURNAL OF TOURISM AND SERVICES}

Issue 22, volume 12, ISSN 1804-5650 (Online)

www.jots.cz

Table 2. CFA measurement model GIF statistics

\begin{tabular}{|c|c|c|c|c|c|c|c|c|c|c|c|}
\hline $\mathbf{X}^{2} / \mathbf{s d}$ & RMSEA & AGFI & GFI & RMR & SRMR & CFI & NFI & NNFI & IFI & RFI & $\begin{array}{c}\text { Model } \\
\text { CAIC/Saturated } \\
\text { CAIC }\end{array}$ \\
\hline $\begin{array}{l}1343.59 / \\
303=4.43\end{array}$ & 0.084 & 0.79 & 0.83 & 0.061 & 0.054 & 0.98 & 0.97 & 0.98 & 0.98 & 0.97 & $1883.32 /$ \\
\end{tabular}

Sources: Çelik \& Yılmaz, 2013; Hair et al., 2010: 666-669; Çokluk et al., 2012: 271-272.

\section{Results}

Table 3 presents the individual characteristics and the distribution of the frequency of purchases for the participants involved in the sample group of the study.

Table 3. Demographic profile of respondents $(n=491)$

\begin{tabular}{llrr}
\hline Variable & Groups & f & \% \\
\hline Sex & Male & 207 & 42.2 \\
Marital Status & Female & 284 & 57.8 \\
& Married & 113 & 23.0 \\
Age & Single & 378 & 77.0 \\
& $18-21$ & 161 & 32.8 \\
& $22-34$ & 217 & 44.2 \\
& $35-44$ & 85 & 17.3 \\
Education Degree & $45-54$ & 23 & 4.7 \\
& 55 and above & 5 & 1.0 \\
& Primary School Graduate & 17 & 3.5 \\
& High School & 119 & 24.2 \\
How often do you go to Starbucks & 34 & 6.9 \\
each month? & Vocational High School & 253 & 51.5 \\
& Undergraduate & 68 & 13.8 \\
& Master's / Doctorate Degree & 117 & 23.8 \\
& $1-3$ Days & 153 & 31.2 \\
& $4-6$ & 145 & 29.5 \\
& 7-9 & 76 & 15.5 \\
\hline
\end{tabular}

Source: own research

According to the data in Table 3, 57.8 percent of the sample group were female, 61.5 percent were aged 22 to 44 years, and 65.3 percent were educated to an undergraduate or post-graduate level. Moreover, while 23.8 percent of the participants visited Starbucks 1-3 times a month, 45 percent of the participants visit Starbucks more frequently than every 7 days.

\subsection{Hypothesis Tests}

While the dependent variable of the research is "brand loyalty", its dependent and intermediary variable is "brand love" and the independent variable is "CBBE". A three-stage SEM approach was used to examine whether brand love was an intervening variable. In this analysis, first of all, the effect of the dependent variable on the intervening variable was examined. In the second stage, the effects of the independent variable and intervening the variable on the dependent variable were examined through a collective analysis. SEM analyses revealed that the impact of the independent variable on the dependent 


\section{JOURNAL OF TOURISM AND SERVICES}

Issue 22, volume 12, ISSN 1804-5650 (Online)

www.jots.cz

variable to have been reduced, and so it could be concluded that the brand love in the model was the intervening variable.

Table 4. GIF statistics of the model for the correlation between CBBE and brand loyalty through brand love

\begin{tabular}{|c|c|c|c|c|c|c|c|c|c|}
\hline Model & $\mathbf{X}^{\mathbf{2}}$ & $\mathbf{s d}$ & $\mathbf{X}^{2} / \mathbf{s d}$ & $\mathbf{P}$ & AGFI & GFI & CFI & NFI & RMSEA \\
\hline Model1 & 1455.94 & 308 & 4.72 & 0.00000 & 0.78 & 0.82 & 0.98 & 0.97 & 0.087 \\
\hline Model2 & 1322.41 & 299 & 4.42 & 0.00000 & 0.80 & 0.83 & 0.98 & 0.97 & 0.084 \\
\hline
\end{tabular}

Source: own research

Table 5. Results of research hypotheses

\begin{tabular}{|c|c|c|c|}
\hline Hypotheses & $\begin{array}{l}\text { Stand. } \\
\text { Loads }\end{array}$ & T-value & Results \\
\hline H1: CBBE $\longrightarrow$ Brand Loyalty & & & Partially Accepted \\
\hline $\mathrm{H} 1_{\mathrm{a}}: \mathrm{SQ}: \mathrm{PQ} \longrightarrow$ Brand Loyalty & 0.25 & $2.67 * *$ & Accepted \\
\hline $\mathrm{H}_{\mathrm{b}} \mathrm{:} \mathrm{SQ}: \mathrm{SB} \longrightarrow$ Brand Loyalty & 0.10 & $2.49 *$ & Accepted \\
\hline $\mathrm{H}_{\mathrm{c}}$ : Ideal Self-Congruence $\longrightarrow$ Brand Loyalty & 0.11 & $0.70^{* * *}$ & Rejected \\
\hline $\mathrm{H}_{\mathrm{d}} \mathrm{d}$ Brand Identification $\longrightarrow$ Brand Loyalty & 0.18 & $2.33^{*}$ & Accepted \\
\hline H1 e: Lifestyle-Congruence $\longrightarrow$ Brand Loyalty & 0.19 & $3.01 * *$ & Accepted \\
\hline H2: $\mathrm{CBBE} \longrightarrow$ Brand Love & & & Partially Accepted \\
\hline $\mathrm{H} 2_{\mathrm{a}}: \mathrm{SQ}: \mathrm{PQ} \longrightarrow$ Brand Love & 0.27 & $3.66^{* *}$ & Accepted \\
\hline $\mathrm{H} 2_{\mathrm{b}}: \mathrm{SQ}: \mathrm{SB} \longrightarrow$ Brand Love & 0.07 & $1.21^{* * *}$ & Rejected \\
\hline $\mathrm{H} 2_{\mathrm{c}}$ : Ideal Self-Congruence $\longrightarrow$ Brand Love & 0.10 & $1.91^{* * *}$ & Rejected \\
\hline $\mathrm{H} 2_{\mathrm{d}}$ : Brand Identification $\longrightarrow$ Brand Love & -0.01 & $-0.09 * * *$ & Rejected \\
\hline H2 $2_{\mathrm{e}}$ Lifestyle-Congruence $\longrightarrow$ Brand Love & 0.51 & $9.56^{* *}$ & Accepted \\
\hline H3: CBBEE $=D$ Brand Love $D$ Brand Loyalty & & & Partially Accepted \\
\hline $\mathrm{H}_{3}: \mathrm{SQ}: \mathrm{PQ} \boldsymbol{\sim} \boldsymbol{D}$ Brand Love Loyalty & $0.27 / 047$ & $\begin{array}{l}3.60^{* * /} \\
7.10^{* *}\end{array}$ & Accepted \\
\hline H33: SQ:SB $\boldsymbol{\sim} \boldsymbol{D B r a n d}$ Love $\boldsymbol{D}$ Brand Loyalty & $0.06 / 0.47$ & $1.05^{* * *}$ & Rejected \\
\hline $\begin{array}{l}\text { H3: Ideal Self-Congruence } \\
\text { Loyalty }\end{array}$ & $0.10 / 0.47$ & $1.91^{* * *}$ & Rejected \\
\hline $\begin{array}{l}\text { H3 } 3_{\mathrm{d}} \text { Brand Identification } \\
\text { Loyalty }\end{array}$ & $-0.02 / 0.47$ & $-0.26^{* * *}$ & Rejected \\
\hline $\begin{array}{l}\text { H3: Lifestyle-Congruence }-\boldsymbol{D} \text { Brand Love } \boldsymbol{D} \boldsymbol{D} \text { Brand } \\
\text { Loyalty }\end{array}$ & $0.52 / 0.47$ & $\begin{array}{l}9.66^{* * /} \\
7.10^{* *}\end{array}$ & Accepted \\
\hline
\end{tabular}
Loyalty

${ }^{* *} \mathrm{p}<.01(\mathrm{t}>2.58),{ }^{*} \mathrm{p}<.05(\mathrm{t}>1.96) ;{ }^{* * *} \mathrm{NS}$ : Not Significant

\begin{tabular}{|l|l|l|}
\hline Direct Effect & $\mathrm{BL}=$ & $\begin{array}{l}0.27 * \mathrm{SQ}: \mathrm{PQ}+0.60 * \mathrm{SQ}: \mathrm{SB}+0.100^{*} \mathrm{ISC}-0.17 * \mathrm{BI}+0.52^{*} \mathrm{LC}, \text { Error var. }=0.30, \\
\mathbf{R}^{2}=\mathbf{0 . 7 0}\end{array}$ \\
\hline Direct Effect & $\mathrm{BLY}=$ & $\begin{array}{l}0.25 * \mathrm{SQ}: \mathrm{PQ}+0.060 * \mathrm{SQ}: \mathrm{SB}+0.100^{*} \mathrm{ISC}+0.19^{*} \mathrm{BI}+0.20^{*} \mathrm{LC}, \text { Error var. }=0.37, \\
\mathbf{R}^{2}=\mathbf{0 . 6 3}\end{array}$ \\
\hline Mediating Effect & $\mathrm{BLY}=$ & $\begin{array}{l}0.47 * \mathrm{BL}+0.12 * \mathrm{SQ}: \mathrm{PQ}+0.15^{*} \mathrm{SQ}: \mathrm{SB}+0.049 * \mathrm{ISC}+0.19 * \mathrm{BI}-0.047 * \text { LC, Error var. }=0.30, \\
\mathbf{R}^{2}=\mathbf{0 . 7 0}\end{array}$ \\
\hline
\end{tabular}




\section{JOURNAL OF TOURISM AND SERVICES}

Issue 22, volume 12, ISSN 1804-5650 (Online)

www.jots.cz

In the model, the "Brand Love" variable fully functions as a mediator in the effects of the "SQ:PQ" and "Lifestyle-Congruence" dimensions on "Brand Loyalty", since it can be observed that the effect of "SQ:SB", "Brand Identification" and "Ideal Self-Congruence" dimensions on "Brand Loyalty" were insignificant, but that an indirect effect can occur by means of "Brand Love". Thus, pursuant to each of the two models, while the sub-hypotheses of $\mathrm{H} 1_{\mathrm{a}}, \mathrm{H} 1_{\mathrm{b}}, \mathrm{H} 1_{\mathrm{d}}, \mathrm{H} 1_{\mathrm{e}}, \mathrm{H} 2_{\mathrm{a}}, \mathrm{H} 2_{\mathrm{e}}, \mathrm{H} 3_{\mathrm{a}}$ and $\mathrm{H} 3_{\mathrm{e}}$ could be accepted, the hypotheses $\mathrm{H} 1, \mathrm{H} 2$ and $\mathrm{H} 3$ were only partially accepted.

\section{Conclusion and Implications}

Nowadays, it's a necessity for the businesses who wants to survive in the intense competition environment to establish long-term relationships with their customers. Businesses must provide symbolic benefits (IS-C, BI, LC) and functional benefits (SQ:PQ, SQ:SB) to their consumers in order to ensure that they establish a bond with the brand. Businesses will strengthen their customers' emotional bond as well their loyalty to the brand in the event that they increase these benefits.

In this study, the aim was to determine the intermediary role of brand love in the relationship between CBBE and brand loyalty. In study, a three-stage SEM approach was used to determine whether or not brand love is an intervening variable. To this end, first of all, the effect of the dependent variable on the intervening variable was examined, while in the second stage, the effects of the independent variable and the intervening variable on the dependent variable were examined through a collective analysis. It was observed that the impact of the independent variable on the dependent variable was reduced, and so it can be accepted in the model that brand love is the intervening variable. Consequently, the $\mathrm{H} 1, \mathrm{H} 2$ and $\mathrm{H} 3$ hypotheses in the study are partially accepted. In the research findings, it has been determined that the "Service Quality: Physical Quality SQ:PQ and Lifestyle-Congruence" dimensions of $\mathrm{CBBE}$ constitute brand loyalty while affecting the intervening variable of brand love. Accordingly, business managers can evoke relatively strong emotional effects as well as various behavioral results such as brand loyalty on consumers as a result through brand love which they can establish by building strong strategies on the dimensions of "Service Quality: Physical Quality SQ:PQ and Lifestyle-Congruence". Moreover, in the study, it has been established that the dimensions of SQ:PQ, SQ:SB, BI and LC have a direct, positive and significant effect on brand loyalty. In their study, Nam, Ekinci and Whyatt (2011) found that IS-C, BI and LC, among the brand equity dimensions, to have a positive effect on brand loyalty. Accordingly, it is demonstrated how deep and meaningful relationships can be built between brands and consumers by means of symbolic consumption. In their study, Susanty and Kenny (2015) found physical quality, ideal self-congruence and lifestyle-congruence to have a positive and significant effect on consumer satisfaction in Excelso and Starbucks. This situation supports the H2a and H2b results of the current study. In their studies to determine the dimensions, Önen (2018), building on the work of Aaker (1991), identified a positive and significant correlation between all of the dimensions of CBBE and brand love. In his study, Souri (2017) found CBBE to have a significant and positive effect on brand loyalty. In the studies of Niyomsart \& Khamwon's (2016), a positive correlation was identified between brand love and brand loyalty.

Brand identity, defined as a unique cluster of brand associations arising out of brand awareness and prestige (Bhattacharya \& Sen, 2003; Ghodeswar, 2008; He \& Mukherjee, 2009), has received the most positive evaluations $(\bar{X}=4.11)$ from the participants among the CBBE dimensions of Starbucks. This situation shows that the Starbucks brand has more influence in terms of brand awareness and associations compared to other brands.

The dimension of staff behavior, referring to the skills, benevolence, sincerity and the sensitivity of the hotel or restaurant employees, (Ekinci et al. 2008; Madanoglu, 2004), has been another dimension which the participants have evaluated positively $(\bar{X}=4.01)$ among the CBBE dimensions of Starbucks. One of the most important policies of the Starbucks company is the importance they give to their staff. 


\section{JOURNAL OF TOURISM AND SERVICES}

Issue 22, volume 12, ISSN 1804-5650 (Online)

www.jots.cz

According to Howard Schultz, "... there is nothing more important than the trust relationship a company builds with its employees", drawing upon his own experience (Starbucks, 2020). This is a strong indicator of the impact company policies can have on the branding of the company, and the motivations of customers to demonstrate a long-term preference for a brand supports the research findings.

Kalyoncuoğlu (2017) supports the current research result by determining that customers' love towards the brand has a positive impact on their brand loyalty. Thus, it is projected that the customers establishing an emotional bond with the brand are strong candidates for being steady customers of the enterprise.

In his study, Sallam (2014) has stated that Brand Identification (BI) has a positive influence on brand love. Moreover, Aydin (2017), brand love has a mediating role in the impact of Ideal SelfCongruence (IS-C) on brand loyalty. These results do not overlap with the current research results. It is predicted that the root cause behind this is that CBBE dimensions implemented in the service industry can be perceived differently according to the manufactured products.

The study has been limited to the customers of 3 Starbucks stores within the city of Mersin, Turkey who were over 18 years of age. While it is expected that the research results will be a guide for the businesses who aspire to provide profitability for the catering enterprises which are among the subsectors of the tourism industry as of the service sector and for those who desire to earn customer loyalty by creating a sustainable competitive advantage in the practice, it is also predicted that it will also contribute to the relevant tourism marketing literature in terms of applying the mediating role of brand love for the first time. The study findings may also contribute to future marketing studies, and may be expanded upon with investigations of the correlation between CBBE, brand love and brand loyalty in other tourism subsectors (such as hotels, airline business, travel agents and tour operators).

\section{References}

1. Aaker, D.A., (1991). Managing brand equity: Capitalizing on the Value of a Brand Name. New York: The Free Press.

2. Aaker, J.L., Fournier, S. \& Brasel, S. A. (2004). When good brands do bad. Journal of Consumer Research, 31 (1),1-16. https://doi.org/10.1086/383419

3. Abdullah, M.I., Sarfraz, M., Arif, A., Azam, A. (2018). An Extension of The Theory of Planned Behavior Towards Brand Equity and Premium Price. Polish Journal of Management Studies, 18 (1), 20-32. https://doi.org/10.17512/pjms.2018.18.1.02

4. Ahuvia, A. C. (1993). I love it! Towards a unifying theory of love across diverse love objects. $\mathrm{PhD}$ dissertation, Northwestern University, Evanston, IL.

5. Ali, F. \& Muqadas, S. (2015). The Impact of Brand Equity on Brand Loyalty: The Mediating Role of Customer Satisfaction. Pakistan Journal of Commerce and Social Sciences, 9 (3), 890-915.

6. Alnawas, I. \& Altarifi, S. (2015). Exploring the role of brand identification and brand love in generating higher levels of brand loyalty. Journal of Vacation Marketing, 22 (2), 111-128. https://doi.org/10.1177/1356766715604663

7. Altunışık R., Coşkun R., Bayraktaroğlu, S. \& Yıldırım, E. (2005). Sosyal Bilimlerde Araştırma Yöntemleri. Adapazarı: Sakarya Kitabevi.

8. Astakhova, M., Swimberghe, K.R. \& Wooldridge, B. R. (2017). Actual and ideal-self congruence and dual brand passion. Journal of Consumer Marketing, 34 (7), 664-672. https://doi.org/10.1108/JCM-10-2016-1985

9. Aşkın, N. \& İpek, İ. (2016). Marka aşkının marka deneyimi ile marka sadakati arasındaki ilişkiye aracilık etkisi. Ege Akademik Bakıss, 16 (1), 79-94. 


\section{JOURNAL OF TOURISM AND SERVICES}

Issue 22, volume 12, ISSN 1804-5650 (Online)

www.jots.cz

10. Aydın, H. (2017). Marka Güveni, farkındalığ1 ve benlik imaj uyumunun marka bağlılığına etkisinde marka aşkının aracılık rolü. Ege Akademik Bakıss, 17 (2), 284-294. https://doi.org/10.21121/eab.2017225205

11. Back, K. J. (2005). The effects of image congruence on customers' brand loyalty in the upper middle-class hotel industry. Journal of Hospitality and Tourism Research, 29 (4), 448-467. https://doi.org/10.1177/1096348005276497

12. Bagozzi, R.P. \& Yi, Y. (1988). On the evaluation of structural equation models. Journal of the Academy of Marketing Science, 16,74-94. https://doi.org/10.1007/BF02723327

13. Başkol, M. \& Asar, İ. (2019). Marka denkliği ve marka aşkı ilișkisi: Kavramsal bir bakıș. Bartın Üniversitesi İktisadi ve İdari Bilimler Fakültesi Dergisi, 10 (20), 110-127.

14. Batra, R., Ahuvia, A.C. \& Bagozzi, R.P.(2012). Brand love. Journal of Marketing, 76 (March), 1-16. https://doi.org/10.1509/jm.09.0339

15. Bhattacharya, C. \& Sen, S. (2003). Consumer-company identification: A framework for understanding consumers' relationships with companies. Journal of Marketing, 67(2),76-88. https://doi.org/10.1509/imkg.67.2.76.18609

16. Bergkvist, L. \& Larsen, T. B. (2010). Two studies of consequences and actionable antecedents of brand love. Journal of Brand Management, 17 (7), 504-518. https://doi.org/10.1057/bm.2010.6

17. Büyükdağ, N. \& Kitapç, O. (2021). Antecedents of consumer-brand identification in terms of belonging brands. Journal of Retailing and Consumer Services, 59, 1-12.

18. Bıçakcıoğlu, N., İpek, İ. \& Bayraktaroğlu, G. (2018). Antecedents and outcomes of brand love: the mediating role of brand loyalty. Journal of Marketing Communications, 24 (8), 863-877. https://doi.org/10.1080/13527266.2016.1244108

19. Boo, S., Busser, J. \& Baloglu, S. (2009). A model of consumer-based brand equity and its application to multiple destinations. Tourism Management, 30 (2). 219-231. https://doi.org/10.1016/j.tourman.2008.06.003

20. Carroll, B.A. \& Ahuvia, A.C. (2006). Some antecedents and outcomes of brand love. Marketing Letters, 17 (2), 79-89. https://doi.org/10.1007/s11002-006-4219-2

21. Chen, C.F. \& Chang, Y.Y. (2008). Airline brand equity, brand preference, and purchase intentions, the moderating effects of switching costs. The Journal of Air Transport Management, 14, 40-43. https://doi.org/10.1016/j.jairtraman.2007.11.003

22. Çelik, H. E. \& Yılmaz, V. (2013). LISREL 9.1 ile Yapısal Eşitlik Modellemesi. İstanbul: Anı Yayınları.

23. Çokluk, Ö., Şekercioğlu, G. \& Büyüköztürk, Ş. (2012). Sosyal Bilimler İcin Çok Değişkenli İstatistike SPSS ve Lisrel Uygulamalar. Ankara: PEGEM Akademi.

24. Filho, C.G., Monteiro, P.R.R. \& Souki, G.Q. (2010). The impacts of brand love, brand equity in the consumer's loyalty and the customer's purchase intentions: The development and testing of alternative models in the automotive sector. 36. ANPAD Congress, 25-29 September, Rio De Janeiro.

25. Fornell, C. \& Larcker, D.F. (1981). Evaluating structural equation models with unobservable variables and measurement error. Journal of Marketing Research, 18, 39-50. https://doi.org/10.1177/002224378101800104

26. Gil, R.B., Andres, E.F. \& Salinas, E.M. (2007). Family as a source of consumer-based brand equity. Journal of Product \& Brand Management, 16 (3), 188-199. https://doi.org/10.1108/10610420710751564

27. Gomez, M.C.O. \& Perez, W.G. (2018). Effects of brand love and brand equity on repurchase intentions of young consumers. International Review of Management and Marketing, 8 (4), 7-13.

28. Grębosz-Krawczyk, M. (2018). The Impact of Nostalgia on the Brand Equity in Economy with Post-Communist Background. Economics and Sociology, 11(2), 216-228. https://doi:10.14254/2071$\underline{789 X .2018 / 11-2 / 15}$ 


\section{JOURNAL OF TOURISM AND SERVICES}

Issue 22, volume 12, ISSN 1804-5650 (Online)

www.jots.cz

29. Hair, J.F., Black, W.C., Babin, B.J. \& Anderson, R.E. (2010). Multivariate Data Analysis A Global Perspective. (7th edt.), Upper Saddle River, NJ, Prentice-Hall.

30. Han, X., Kwortnik, R.J. \& Wang, C. (2008). Service loyalty: an integrative model and examination across service contexts. Journal of Service Research, 11 (1), 22-42. https://doi.org/10.1177/1094670508319094

31. He, H., Li, Y. \& Harris, L. (2012). Social identity perspective on brand loyalty. Journal of Business Research, 65, 648-657. https://doi.org/10.1016/i.jbusres.2011.03.007

32. Hemsley-Brown, J. \& Alnawas, I. (2016). Service quality and brand loyalty: The mediation effect of brand passion, brand affection and self-brand connection. International Journal of Contemporary Hospitality Management, 28 (12), 2771-2794. https://doi.org/10.1108/IJCHM-09-2015-0466

33. Jorfi, S. \& Gayem, A. (2016). Brand equity, brand loyalty and consumer satisfaction (Case study consumer goods of brand Samsung in shops of Khuzestan). International Journal of Humanities and Cultural Studies, Special Issue (January), 1981-1986.

34. Kalyoncuoğlu, S. (2017). Markaya duyulan güven ile marka sadakati ilişkisinde marka aşkının arac1lık rolü: Starbucks markası üzerine bir araştırma. Journal of Tourism and Gastronomy Studies, 5 (4), 383-402. https://doi.org/10.21325/jotags.2017.156

35. Kamat, V.\& Parulekar, A.A. (2007). Brand love-the precursor to loyalty. The Twenty-Sixth Advertising and Consumer Psychology (ACP) conference, New Frontiers in Branding: Attitudes, Attachments, and Relationships. Santa Monica, CA, June 7-9.

36. Keller, K.L. (2008). Strategic Brand Management. (12th ed.) Upper Seddle River: Prentice-Hall.

37. Keller, K.L.(1993) Conceptualizing, measuring, and managing customer-based brand equity. Journal of Marketing, 57, 1-22. https://doi.org/10.2307/1252054

38. Kim, R. B. \& Chao, Y. (2018). The effect of country of origin on consumer-based brand equity $(\mathrm{CBBE})$ of Colombian consumers: An empirical investigation of Samsung vs. Huawei brands. Lournal of International Studies, 11(3), 70-81. https://doi:10.14254/2071-8330.2018/11-3/6

39. Kim, W. G., Jin-Sun, B. \& Kim, H. J. (2008). Multidimensional customer-based brand equity and its consequences in midpriced hotels. Journal of Hospitality \& Tourism Research, 32 (2), 235-254. https://doi.org/10.1177/1096348007313265

40. Köksal, C.D. \& Demir, M.Ö. (2012). The impacts of self-brand congruence on brand loyalty: A study on cellular phone users. International Journal of Social Sciences and Humanity Studies, 4 (2), 91 100.

41. Loureiro, S. M., Ruediger, K. H. \& Demetris, V. (2012). Brand emotional connection and loyalty. Journal of Brand Management, 20 (1), 13-27. https://doi.org/10.1057/bm.2012.3

42. Nam, J., Ekinci, Y. \& Whyatt, G. (2011). Brand equity, brand loyalty and consumer satisfaction. Annals of Tourism Research, 38, 1009-1030. https://doi.org/10.1016/j.annals.2011.01.015

43. NEA (National Education Asociation) (1965). Sampling and statistic handbook for surveys in education. Washington, USA: National Education Asociation Press.

44. Niyomsart, S. \& Khamwon, A. (2016). Brand love, brand loyalty and word of mouth: A case of airasia. Conference of the International Journal of Arts \& Sciences, 09 (01), 263-268.

45. NTV (2020). En değerli markalar belli oldu. Retrieved April 07, 2021, from https://www.ntv.com.tr/galeri/ekonomi/en-degerli-markalar-belli-oldu,exaLGzSq60ypJF CfQ1Khxg/eAD0DWyg0UygGbxH-NauuA

46. Madanoğlu, M. (2004). Validating restaurant service quality dimensions. Journal of Foodservice Business Research, 7 (4), 127-147. https://doi.org/10.1300/J369v07n04 07

47. Majerova, J. (2020). Monistic concept of branding has been broken: How to guarantee consistency in brand value management?. Polish Journal of Management Studies, 22 (2), 232-246. https://doi.org/10.17512/pjms.2020.22.2.16 


\section{JOURNAL OF TOURISM AND SERVICES}

Issue 22, volume 12, ISSN 1804-5650 (Online)

www.jots.cz

48. Majerova, J., Sroka, W., Krizanova, A., Gajanova, L., Lazaroiu, G. \& Nadanyiova, M. (2020). Sustainable brand management of alimentary goods. Sustainability, 12 (2), 556. https://doi.org/10.3390/su12020556

49. Ongkowidjoyo, H. (2015). The impact of brand equity towards customer loyalty of Starbucks: Testing the role of customer satisfaction as the mediate variable. iBuss Management, 3 (2), 186-195.

50. Önen, V. (2018). Marka değerinin marka aşkına etkisinin incelenmesi: Starbucks Cafe Örneği. Avrasya Sosyal ve Ekonomi Arastirmalar Dergisi, 5 (1), 49-63.

51. Park, C., MacInnis, D.J., Priester, J., Eisingerich, A.B. \& Iacobucci, D. (2010). Brand attachment and brand attitude strength: conceptual and empirical differentiation of two critical brand equity drivers. Journal of Marketing, 74 (6), 1-17. https://doi.org/10.1509/jmkg.74.6.1

52. Peter, J.P. (1981). Construct validity: A review of basic issues and marketing practices. Journal of Marketing Research, 18, 133-145. https://doi.org/10.2307/3150948

53. Ranjbarian, B. Kazemi, A. \& Borandegi, F. (2013). Analyzing the antecedents and consequences of brand love with a case study on Apple cell phone users. International Journal of Academic Research in Business and Social Sciences, November, 3-11. http://dx.doi.org/10.6007/IJARBSS/v3 i11/341

54. Rather,R.A. \& Camilleri, M.A. (2019). The effects of service quality and consumer-brand value congruity on hospitality brand loyalty. Anatolia, 30 (4), 547-559. https://doi.org/10.1080/13032917.2019.1650289

55. Roberts, K. (2004). "Aşk"l Markalar Daha Cok Satzyor. Retrieved November 13, 2020, from https://www.capital.com.tr/yonetim/pazarlama/askli-markalar-daha-cok-satiyor

56. Rodrigues, P. \& Reis, R. (2013). The influence of "brand Love" in consumer behavior - the Case of Zara and Modalfa brands. Proceedings of 22nd International Business Research Conference, (September), 9-10.

57. Rosenberg, M. (1979). Conceiving the self. New York: Basic Books.

58. Sallam, M. A. (2014). The effects of brand image and brand identification on brand love and purchase decision making: The role of WOM. International Business Research, 7 (10), 187-193. https://doi:10.5539/ibr.v7n10p 187

59. Sekaran, U. (2003). Research methods for business. New York: John Wiley High Education Press.

60. Sirgy, M., Grewal, D. \& Mangleburg, T. (2000). Retail environment, self-congruity, and retail patronage: An integrative model and a research agenda. Journal of Business Research, 49 (2), 127-138. https://doi.org/10.1016/S0148-2963(99)00009-0

61. Shahroodi, H. M., Kaviani, H. \& Abasian, M. R. (2015). Evaluating the effect of brand equity on consumer satisfaction and brand loyalty in large retails of the Mazandaran Province (Case Study: Food Products Industry). European Online Journal of Natural and Social Sciences, 4 (1), 1-12.

62. Shin, C.S., Hwang, G.S., Lee, H. \& Cho, S.R. (2015). The impact of Korean franchise coffee shop service quality and atmosphere on customer satisfaction and loyalty. East Asian Journal of Business Management, 5 (4), 47-57. https://doi.org/10.13106/eajbm.2015.vol5.no4.47

63. Starbucks (2019). Starbucks. Retrieved November 10, 2020, from https://www.starbucks.com.tr/

64. Starbucks (2021). Starbucks. Retrieved April 07, 2021, from https://www.starbucks.com.tr/media/AboutUs-Company_Profile-7.21.16_tcm95-21033.pdf

65. Susanty, A. \& Kenny, E. (2015). The relationship between brand equity, customer satisfaction, and brand loyalty on coffee shop: Study of excelso and starbucks. Asean Marketing Journal, 7 (1), 14-27. https://doi/org/10.21002/amj.v7i1.4481

66. Souri, F. (2017). Investigate the relationship between brand equity, brand loyalty and customer satisfaction. International Journal of Scientific \& Technology Research, 6 (6), 225-231.

67. Sürücü, Ö., Öztürk, Y., Okumuş, F. \& Bilgihan, A.(2019). Brand awareness, image, physical quality and employee behavior as building blocks of customer-based brand equity: Consequences in the hotel context. Journal of Hospitality and Tourism Management, 40, 114-124. https://doi.org/10.1016/i.jhtm.2019.07.002 


\section{JOURNAL OF TOURISM AND SERVICES}

Issue 22, volume 12, ISSN 1804-5650 (Online)

www.jots.cz

68. Şimşek, H. H. (2019). Havayolu sektöründe marka kişiliği ve marka denkliği arasindaki ilişkiye yönelik bir uygulama. (Unpublished Master Thesis), Hacettepe Üniversitesi, Ankara.

69. Şimşek, Ö. F. (2007). Yapisal eşitlik modellemesine giris temel ilkeler ve lisrel uygulamalar. Ankara: Ekinoks Eğitim ve Danışmanlık Hizmetleri.

70. Thomson, J., MacInnis, K. \& Park, W. (2005). The ties that bind: measuring the strength of consumers' attachments to brands. Journal of Consumer Psychology, 15 (1), 77-90. https://doi/org/10.1207/S15327663JCP1501 10

71. Tanushan, K., Kennedy, F.B. (2020). Brand equity and brand loyalty: The mediating effect of customer satisfaction a comparative study on companies with brand change. International Journal of Scientific and Research Publications, 10 (12), 456-469. https://doi/org/10.29322/IJSRP.10.12.2020.p10850

72. Tu, Y., Wang, C. \& Chang, H. (2012). Corporate brand image and customer satisfaction on loyalty: an empirical study of Starbucks coffee in Taiwan. Journal of Social and Development Sciences, 3 (1), 24-32. https://doi/org/10.22610/JSDS.V3I1.682

73. Ural A. \& Kılıç İ. (2006). Bilimsel Araştırma Süreci ve SPSS ile Veri Analiz̨i. Ankara: Detay Yayıncılık.

74. Ünal, S. \& Aydin, H. (2013). An investigation on the evaluation of the factors affecting brandlove. ProcediaSocial and Behavioral Sciences, 92, 76-85. https://doi.org/10.1016/i.sbspro.2013.08.640

75. Vázquez, R.A., Río, B.D. \& Iglesias, V. (2002). Consumer-based brand equity: Development and validation of a measurement instrument. Journal of Marketing Management, 18:1-2, 27-48. https://doi.org/10.1362/0267257022775882

76. Yasin. M.N, Noor, M.N. \& Mohamad, O. (2007). Does image of country origin matter to brand equity. Journal of Product and Brand Management, 16 (1), 38-48. https://doi.org/10.1108/10610420710731142

77. Yazıcıoğlu, Y. \& Erdoğan, S. (2004). SPSS Uygulamalı Bilimsel Araștırma Yöntemleri. Ankara: Detay Yayıncilik.

78. Yoo, B. (2009). Cross-national invariance of the effect of personal collectivistic orientation on brand loyalty and equity. Asia Pacific Journal of Marketing and Logistics, 21 (1), 41-57. https://doi.org/10.1108/13555850910926236

79. Yoo, B., Donthu, N. \& Lee, S. (2000). An examination of selected marketing mix elements and brand Equity. Journal of the Academy of Marketing Science, 28 (2), 195-211. https://doi.org/10.1177/0092070300282002

80. Zeitham, V., Berry, L. \& Parasuraman, A. (1996). The behavioral consequences of service quality. Journal of Marketing, 60, 31-46. https://doi.org/10.1177/002224299606000203

\section{Brief description of Authors:}

\section{Aylin Sinem Polat}

ORCID ID: https://orcid.org/0000-0002-3323-8598

Aylin Sinem Polat graduated from Bolu Izzet Baysal University, Department of Gastronomy and Culinary Arts. She completed her master's degree in Mersin University, Department of Gastronomy and Culinary Arts. She has academic studies in the food and beverage business.

e-mail: aylinsinempolat@gmail.com

\section{Burçin Cevdet Çetinsöz, PhD}

ORCID ID: https://orcid.org/0000-0003-1703-8067

Burçin Cevdet Çetinsöz graduated from Gazi University Tourism Management. He completed his master's degree at Mersin University. He completed his doctorate at Adnan Menderes University. He 


\section{JOURNAL OF TOURISM AND SERVICES}

Issue 22, volume 12, ISSN 1804-5650 (Online)

www.jots.cz

works at Alanya Alaaddin Keykubat University. He has academic researchs in the field of tourism management.

e-mail: burcin.cetinsoz@alanya.edu.tr

Appendix 1. Scales (5-point Likert scale: '1' Disagree Strongly and '5' Agree Strongly)

\begin{tabular}{|c|c|c|}
\hline Factors & Items & Abbrev \\
\hline \multirow{6}{*}{$\begin{array}{c}\text { Service } \\
\text { Quality: } \\
\text { Physical } \\
\text { Quality }\end{array}$} & Starbucks has modern-looking equipment. & SQ:PQ1 \\
\hline & $\begin{array}{l}\text { Materials associated with service provision (such as menus, furniture) are visually } \\
\text { appealing. }\end{array}$ & SQ:PQ2 \\
\hline & The Starbucks brand has an atmosphere that "makes me feel at home". & SQ:PQ3 \\
\hline & The Starbucks brand offers good Wi-fi connectivity. & SQ:PQ4 \\
\hline & The drinks served by the Starbucks brand suit my taste. & SQ:PQ5 \\
\hline & The food served by the Starbucks brand suits my taste. & SQ:PQ6 \\
\hline \multirow{4}{*}{$\begin{array}{c}\text { Service } \\
\text { Quality: Staff } \\
\text { Behavior }\end{array}$} & Employees of Starbucks always listen to customer complaints. & SQ:SB1 \\
\hline & Employees of Starbucks are helpful, e. g. In helping me choose what to purchase. & SQ:SB2 \\
\hline & Employees of Starbucks are friendly to Customers. & SQ:SB3 \\
\hline & Employees of Starbucks are competent in their jobs. & SQ:SB4 \\
\hline \multirow{3}{*}{$\begin{array}{l}\text { Ideal Self- } \\
\text { congruence }\end{array}$} & $\begin{array}{l}\text { The typical Starbucks customer has an image similar to how I would like to see } \\
\text { myself. }\end{array}$ & IS-C1 \\
\hline & The image of Starbucks is consistent with how I would like to see myself. & IS-C2 \\
\hline & The image of Starbucks is consistent with how I would like others to see me. & IS-C3 \\
\hline \multirow{4}{*}{$\begin{array}{l}\text { Brand } \\
\text { Identification }\end{array}$} & The Starbucks brand has a distinctive identity. & BI1 \\
\hline & The Starbucks brand stands out from its competitors. & $\mathrm{BI} 2$ \\
\hline & Starbucks is a first-class, high-quality brand. & $\mathrm{BI} 3$ \\
\hline & The Starbucks brand has a high reputation. & BI4 \\
\hline \multirow{3}{*}{$\begin{array}{c}\text { Lifestyle- } \\
\text { Congruence }\end{array}$} & Starbucks reflects my personal lifestyle. & LC1 \\
\hline & Starbucks is totally in line with my lifestyle. & LC2 \\
\hline & Starbucks supports my lifestyle. & LC3 \\
\hline
\end{tabular}




\section{JOURNAL OF TOURISM AND SERVICES}

Issue 22, volume 12, ISSN 1804-5650 (Online)

www.jots.cz

\begin{tabular}{|c|c|c|}
\hline \multirow{9}{*}{ Brand Love } & Starbucks is a wonderful brand & BL1 \\
\hline & Starbucks makes me feel good. & BL2 \\
\hline & Starbucks makes me very happy. & BL3 \\
\hline & I'm in love with Starbucks. & BL4 \\
\hline & I am passionate about Starbucks. & BL5 \\
\hline & I am very attached to Starbucks. & BL6 \\
\hline & I feel like I am whole with Starbucks. & BL7 \\
\hline & Starbucks is a pure delight. & BL8 \\
\hline & Starbucks is totally awesome. & BL9 \\
\hline \multirow{4}{*}{$\begin{array}{c}\text { Brand } \\
\text { Loyalty }\end{array}$} & I would recommend this brand to someone seeking my advice. & BLY1 \\
\hline & I will continue to use Starbucks products. & BLY2 \\
\hline & I would not switch to other brands if I experience a problem with this brand. & BLY3 \\
\hline & I encourage friends and relatives to do business with Starbucks. & BLY4 \\
\hline
\end{tabular}

